Revta brasil. Bot., São Paulo, V.24, n.4, p.415-424, dez. 2001

\title{
Morphology and anatomy in Heliconia angusta Vell. and H. velloziana L. Emygd. (Zingiberales: Heliconiaceae) from the Atlantic forest of southeastern Brazil
}

\author{
DANIELA GUIMARÃES SIMÃO ${ }^{1,2}$ and VERA LUCIA SCATENA ${ }^{1}$
}

(received: December 13, 2000; accepted: August 1, 2001)

\begin{abstract}
Morphology and anatomy in Heliconia angusta Vell. and H. velloziana L. Emygd. (Zingiberales: Heliconiaceae) from the Atlantic forest of southeastern Brazil). Morphological and anatomical features of roots, stems, leaves, and scapes were studied in Heliconia angusta and $H$. velloziana from the Atlantic forest in the southeastern of Brazil. Morphologically $H$. angusta and $H$. velloziana show differences in their sizes, blade shapes, number and shape of inflorescence bracts. On the other hand, they have common anatomical characteristics such as: roots with air-canals in the cortex; rhizomes with isolated fiber bundles, collateral vascular bundles, and uniseriate endodermis and pericycle; leaves presenting air-canals and collateral vascular bundles forming arcs, and thin-walled epidermal cells; scapes with collateral vascular and fiber bundles in the cortex. The distribution of the fiber bundles in the leaves and in the scapes was different for each species, having a taxonomical value, H. velloziana presenting continuous fiber bundles. Air-canals in roots and leaves with narrow mesophyll might be related to the moist understorey of the Atlantic forest habitats.
\end{abstract}

RESUMO - (Morfologia e anatomia de Heliconia angusta Vell. and H. velloziana L. Emygd. (Zingiberales: Heliconiaceae) em Mata Atlântica, no sudeste do Brasil). Foram estudados os caracteres morfo-anatômicos das raízes, caules, folhas e escapos de Heliconia angusta e H. velloziana, provenientes de Mata Atlântica, no sudeste do Brasil. Do ponto de vista morfológico, $H$. angusta e $H$. velloziana apresentam diferenças de: tamanho dos indivíduos, forma das lâminas foliares, número e forma das brácteas da inflorescência. Possuem caracteres anatômicos em comum, tais como: raízes com canais de ar no córtex; rizomas com feixes de fibras isolados, feixes vasculares colaterais e endoderme e periciclo unisseriados; folhas apresentando canais de ar, feixes vasculares colaterais formando arcos e células epidérmicas com paredes pouco espessadas; escapos com feixes vasculares colaterais e feixes de fibras no córtex. A distribuição dos feixes de fibras, encontrada nas folhas e nos escapos, difere em cada espécie, possuindo então um valor diagnóstico, $H$. velloziana apresenta feixes de fibras contínuos. Canais de ar nas raízes e folhas com mesofilo estreito são caracteres que provavelmente podem estar relacionados com o habitat úmido, do subosque de Mata Atlântica.

Key words - H. angusta, H. velloziana, morphology, anatomy, vegetative organs

\section{Introduction}

In the Zingiberales, a primarily tropical order of monocotyledons, most taxonomists recognize eight families: Musaceae, Strelitziaceae, Lowiaceae, Heliconiaceae, Zingiberaceae, Costaceae, Cannaceae and Marantaceae (Nakai 1941, Tomlinson 1962, Cronquist 1981, Dahlgren et al. 1985, Kress 1990a, b). Most of the tropical members of these families are found in Brazil (Kress 1990a).

The family Heliconiaceae comprises a single genus, Heliconia L., with 250-300 species, distributed mainly in Neotropical areas, from the North of Mexico to the South of Brazil (Santos 1978, Cronquist 1981, Dahlgren et al. 1985, Kress 1990a). A small

1. Universidade Estadual Paulista, Departamento de Botânica, Caixa Postal 199, 13506-900 Rio Claro, SP, Brazil.

2. Corresponding author: dgsimao@rc.unesp.br
Paleotropical group, about eight species, occurs in islands of the South Pacific (Tomlinson 1969, Kress 1985). There are approximately 40 Brazilian species, with two primary areas of distribution: the Amazon basin and the Atlantic coastal forest (Kress 1990a).

The anatomy of the vegetative organs can provide valuable evidence in taxonomic research. Generally, the anatomical studies of the genus Heliconia (Tomlinson 1959, 1962, 1969, Triplett \& Kirchoff 1991, Rundel et al. 1998) do not include endemic Brazilian species, only widespread species, or endemic species from other areas, or others that are widely cultivated.

This paper describes the morphological and anatomical features of the vegetative organs of Heliconia angusta and $H$. velloziana, both endemic species of the Atlantic forest. These data can be useful in taxonomy, as well as to indicate the possible environmental adaptations that can occur in the studied area. 


\section{Material and methods}

Study site - "Núcleo Picinguaba" is an environmental protection area, around 8.500 ha, and it is located in the municipality of Ubatuba, State of São Paulo, Brazil, belonging to "Serra do Mar" State Park. The climate is little seasonal without a dry season, and the vegetation is mosaic-like, with different physiognomies, including dunes, mangroves, restingas and Atlantic coastal forest (Cesar \& Monteiro 1995). Studied species - Voucher specimens of Heliconia angusta and $H$. velloziana have been deposited in the Herbarium Rioclarense (HRCB), Universidade Estadual Paulista: Heliconia angusta: Simão et al. 13; Simão et al. 14; Simão et al. 15 ; H. velloziana: Simão et al. 04; Simão et al. 07; Simão et al. 16. The specimens were collected mainly on the forest, $H$. angusta was found mainly in shaded places but also at the border of the forest, and H. velloziana was found in open areas, both species found in moist places.

Morphological and anatomical studies - Morphological observations were based on natural populations. For anatomical studies using the light microscope, free-hand cross sections were made in the median part of young and mature roots and rhizomes, and at different levels of leaves and scapes fixed in 50\% FAA (Johansen 1940). These sections were stained with fuchsin and astra blue (Roeser 1962) and mounted in glycerine jelly. Five specimens were used for both morphological and anatomical studies.

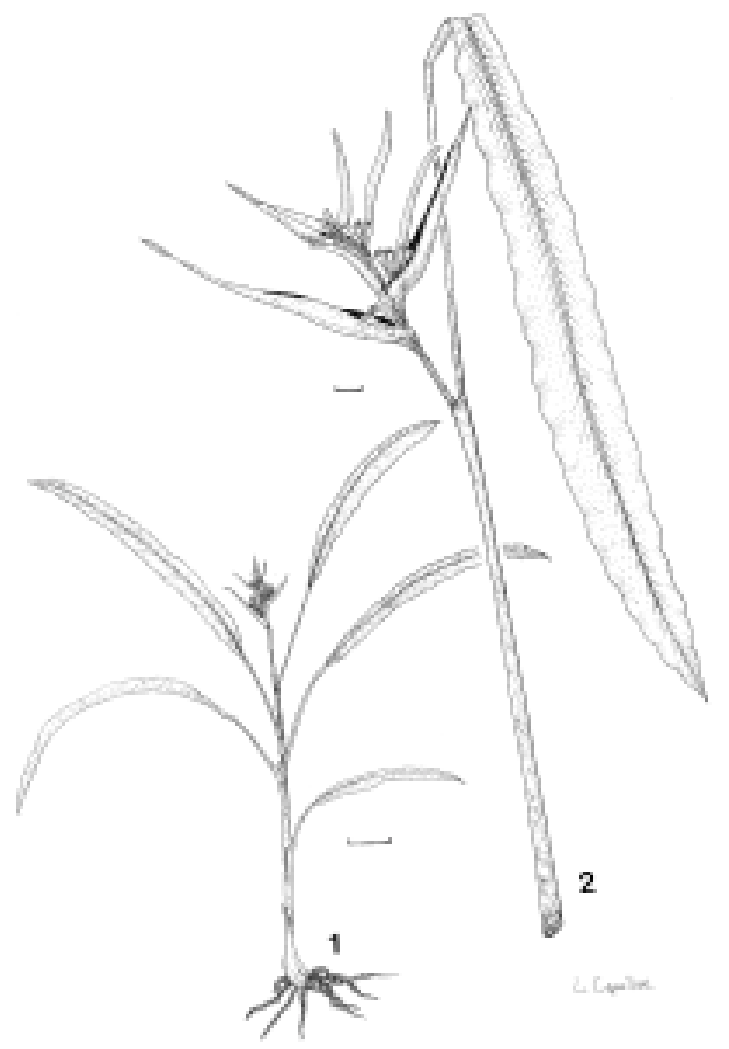

Figures 1-2. Heliconia angusta. 1. Habit. Bar $=10 \mathrm{~cm} .2$. Leaf and inflorescence with three opened bracts. Bar $=1 \mathrm{~cm}$.

\section{Results}

Morphological aspects - Heliconia angusta and $H$. velloziana are perennial herbs with sympodial rhizomes which have very short internodes. The rhizomes bear delicate brownish adventitious roots, and the aerial parts of these plants are characterized by leaves, scape and a compound inflorescence. Each leaf presents an open leaf-sheath with over-wrapping margins, a long cylindrical petiole, and a blade with an asymmetrical base. The inflorescence is terminal, with an erect orientation, composed of distichouslyarranged bracts, each bract subtending a cincinnus of flowers (figures 1-4). The mature fruits are blue drupes.

Morphological differences of $H$. angusta and $H$. velloziana are shown in table 1.

Roots - In $H$. angusta and $H$. velloziana roots, the uniseriate epidermis has thin-walled cells, which are intact only in young roots (figures 5,6 ); remains of these epidermal cells can be observed in the mature ones (figure 7).

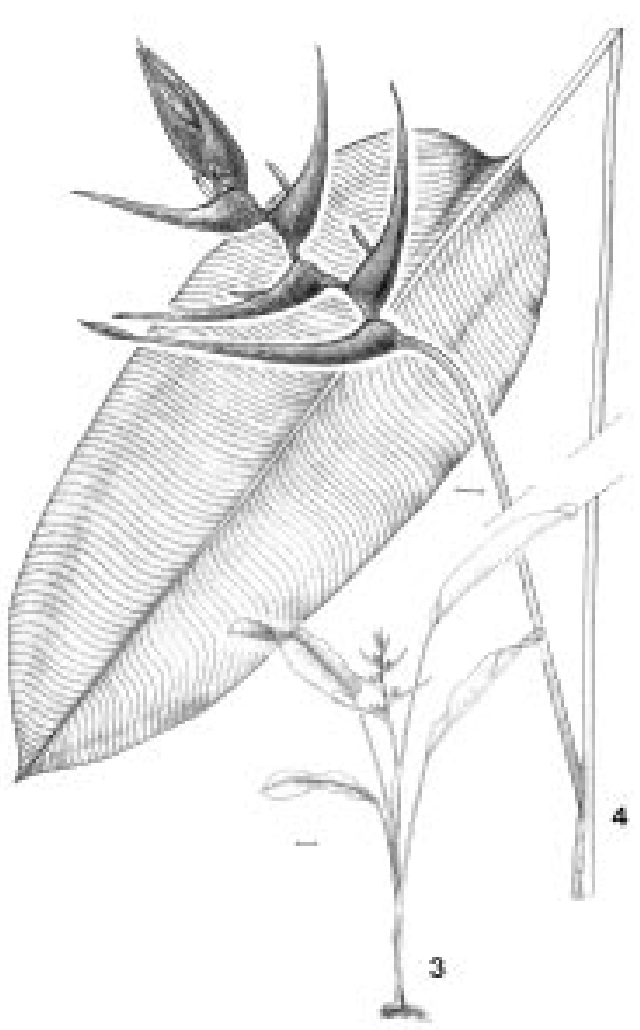

Figures 3-4. H. velloziana. 3. Habit. Bar $=10 \mathrm{~cm}$. 4. Leaf and inflorescence with five opened bracts. Bar $=2 \mathrm{~cm}$. 
Table 1. Morphological differences between H. angusta and H. velloziana.

\begin{tabular}{llllll}
\hline Species & \multicolumn{3}{c}{ Characteristics } & \\
\cline { 2 - 6 } & $\begin{array}{c}\text { Plant height } \\
(\mathrm{m})\end{array}$ & Blade shape & $\begin{array}{l}\text { Number, shape and } \\
\text { color of bracts }\end{array}$ & $\begin{array}{l}\text { Number of } \\
\text { flowers per } \\
\text { cincinnus }\end{array}$ & Flower color \\
\hline H. angusta $(\mathrm{n}=5)$ & $0.60-1.75$ & $\begin{array}{l}\text { linear-oblong, } \\
\text { cuneate base and } \\
\text { acuminate apex }\end{array}$ & $\begin{array}{l}\text { 6-7 conduplicate- } \\
\text { lanceolate and } \\
\text { pinkish red }\end{array}$ & ca. 5 & $\begin{array}{l}\text { white sepals and } \\
\text { petals, orange } \\
\text { ovary and pedicel }\end{array}$ \\
H. velloziana $(\mathrm{n}=5)$ & $2.20-3.50$ & $\begin{array}{l}\text { elliptic-oblong, } \\
\text { obtuse base and } \\
\text { acute apex }\end{array}$ & $\begin{array}{l}8-10 \text { cymbiform } \\
\text { and orange red }\end{array}$ & ca. 10 & $\begin{array}{l}\text { greenish yellow } \\
\text { sepals, petals and } \\
\text { ovary, and white } \\
\text { pedicel }\end{array}$ \\
\hline
\end{tabular}

The exodermis is represented by 1-3 layers of slightly thick-walled cells, especially the external periclinal wall (figures 5-7). Radial air-canals are present in the cortex (figure 5). Exodermal cells and cells of the outer cortex have variable shapes, without intercellular spaces (figures 5-7), while internal ones have isodiametric cells with intercellular spaces arranged in radial rows (figures 5, 8, 9). The endodermis is uniseriate, the cells with a rounded lumen and lignified anticlinal and internal periclinal walls, which become U-shaped in the mature roots (figure 9). Casparian strips are visible only in young roots (figure 8).

The pericycle consists of a uniseriate layer of rectangular thin-walled cells (figure 9). The stele is polyarch, and includes radially extended phloem strands (figure 9). The pith has thin-walled cells in young roots, and thick-walled cells in mature ones (figure 9). Raphide sacs are common in the cortex of both young and mature roots.

Rhizomes - The rhizomes present isolated fiber bundles and vascular bundles (figure 10) in the cortex of both studied species. Cortical vascular bundles are collateral with fibers close to the phloem (figure 10). The uniseriate endodermis presents slightly rounded cells, and the periclinal internal walls are not thickened (figure 11).

The uniseriate pericycle has rectangular thinwalled cells (figure 11). Collateral vascular bundles can be partially (figure 11) or totally enclosed by fibers. The cortex and the vascular cylinder of the rhizome have large quantities of starch grains (figure 10) and also raphide sacs and idioblasts with phenolic substances (figures 10, 11).
Leaves - In the leaf-sheath (figures 12, 13), petiole (figures 14, 15) and midrib region (figures 16, 17) of $H$. angusta and $H$. velloziana the vascular bundles form 1-3 discrete vascular systems: the main vascular system (I), between two arcs of air-canals, forming a single extensive arc; the abaxial vascular system (II), generally forming more than one arc; and the adaxial vascular system (III), forming only a small arc. The vascular bundles are collateral and enclosed by a double-sheath: the external one of endodermal origin, with thin-walled cells, and the internal one of pericyclic origin, with thick-walled cells (figures 26, 27). In both species, inclined vascular bundles can be observed in the proximal part of the leaf-sheath (figures 18, 19) and midrib region.

Fiber bundles were found close to the abaxial vascular system (figures 12-18, 22, 23), forming almost a continuous cylinder in $H$. velloziana (figures 13 , $15,17,23)$, while in $H$. angusta these fiber bundles are discontinuous (figures 12, 14, 16, 18, 22).

Air-canals are also arranged in arcs, consisting of an abaxial and adaxial systems, each of them with only one series (figures 12-17). These air-canals form compartments defined by diaphragms. These diaphragms are constituted by stellate cells (figure 24). Raphide sacs are generally present in some of these diaphragms (figure 25).

Epidermal cells are uniseriate, with adaxial cells larger than the abaxial ones (figures 26, 27). Paracytic stomata occur only on the abaxial surface (figure 26).

Cortical cells of the leaf-sheath and of petiole are isodiametric, and the external layers consist of chlorenchyma (figures 20, 21, 23). This tissue encloses the peripheral vascular and fiber bundles, 

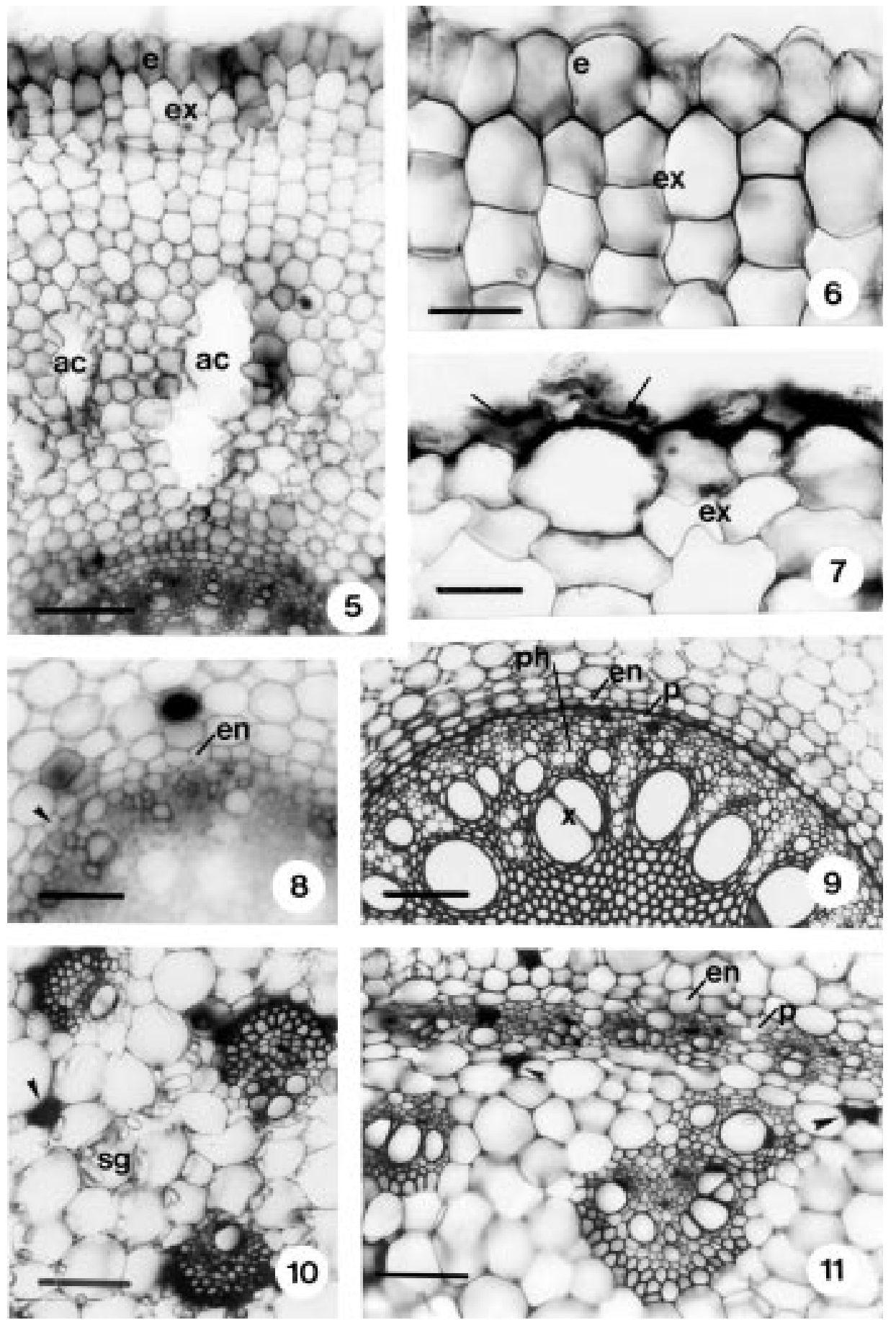

Figures 5-11. Root and rhizome cross sections of Heliconia spp. 5. Young root of H. angusta. Epidermis (e), exodermis (ex), and air-canals (ac) in the inner cortex. Bar $=100 \mu \mathrm{m}$. 6. Epidermis (e) and exodermis (ex) Bar $=50 \mu \mathrm{m}$. 7. Remains of epidermal cells (arrows) and the exodermis (ex) of mature $H$. velloziana root. Bar $=50 \mathrm{~mm}$. 8. Endodermis (en) with Casparian strips (arrow) and stele of young $H$. angusta root. Bar $=50 \mu \mathrm{m}$. 9. Endodermis (en) and stele of mature H. velloziana root. Pericycle (p); phloem (ph); xylem (x). Bar $=100 \mu \mathrm{m}$. 10-11. Rhizomes of H. velloziana. 10. Cortical vascular bundles and starch grains (sg), the arrow shows idioblast with phenolic substances. Bar $=100 \mu \mathrm{m} .11$. Endodermis (en) and cylinder vascular bundles, arrows show idioblast with phenolic substances. Pericycle (p). Bar $=100 \mu \mathrm{m}$. 

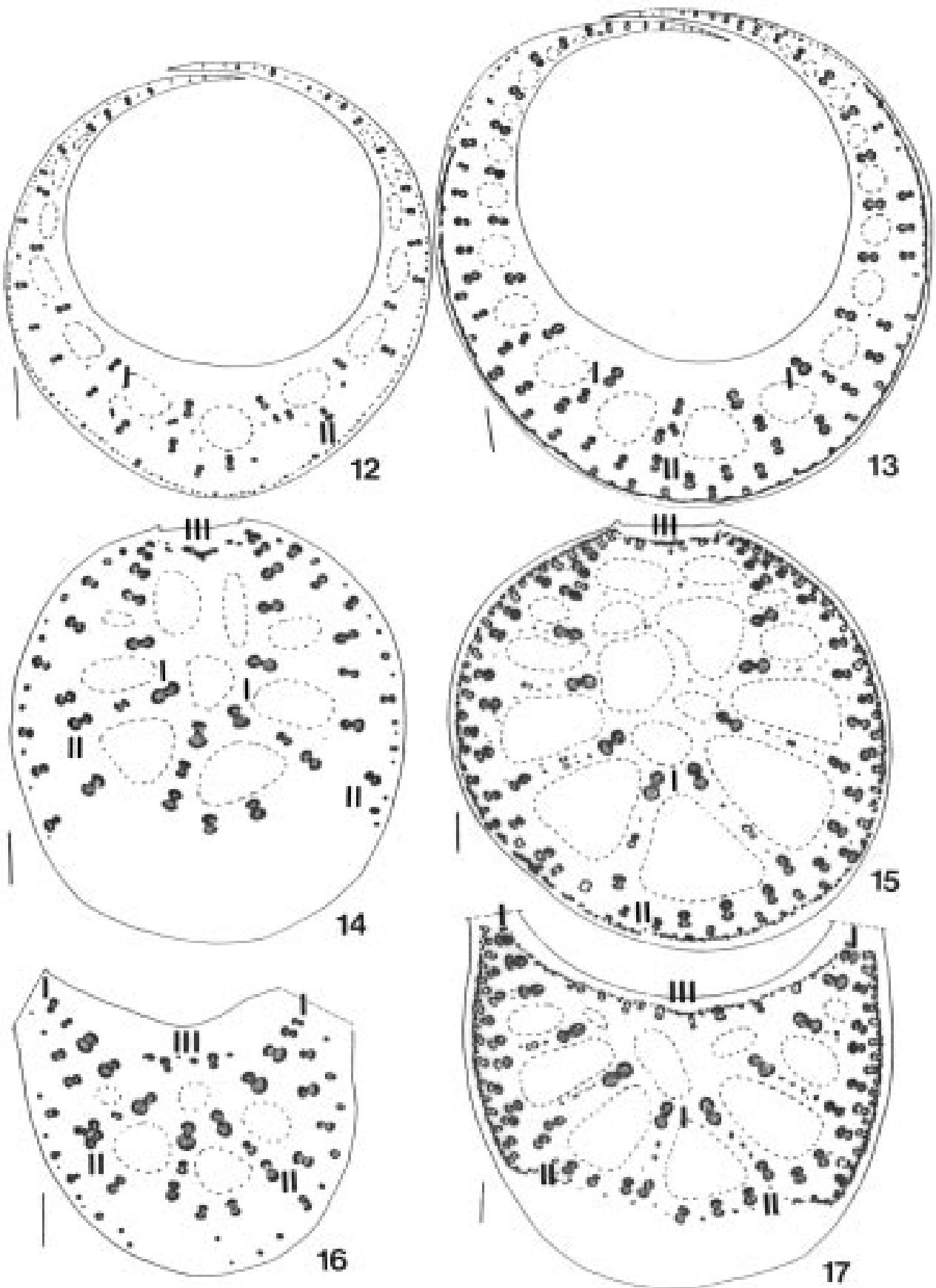

epidernis

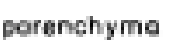

fibers

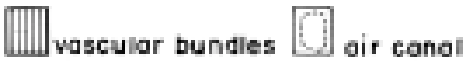

Figures 12-17. Diagrams of Heliconia spp. leaves. 12-13. Proximal part of the leaf-sheath. 12. H. angusta. Bar $=1 \mathrm{~mm} .13$. H. velloziana. Bar $=1 \mathrm{~mm}$. 14-15. Distal part of the petiole. 14. H. angusta. Bar $=0,5 \mathrm{~mm} .15$. H. velloziana. Bar $=0,5 \mathrm{~mm}$. 16-17. Proximal part of the midrib region 16. H. angusta. Bar $=0,5 \mathrm{~mm} .17$. H. velloziana. Bar $=0,5 \mathrm{~mm}$. Main vascular system (I); abaxial vascular system (II); adaxial vascular system (III). 

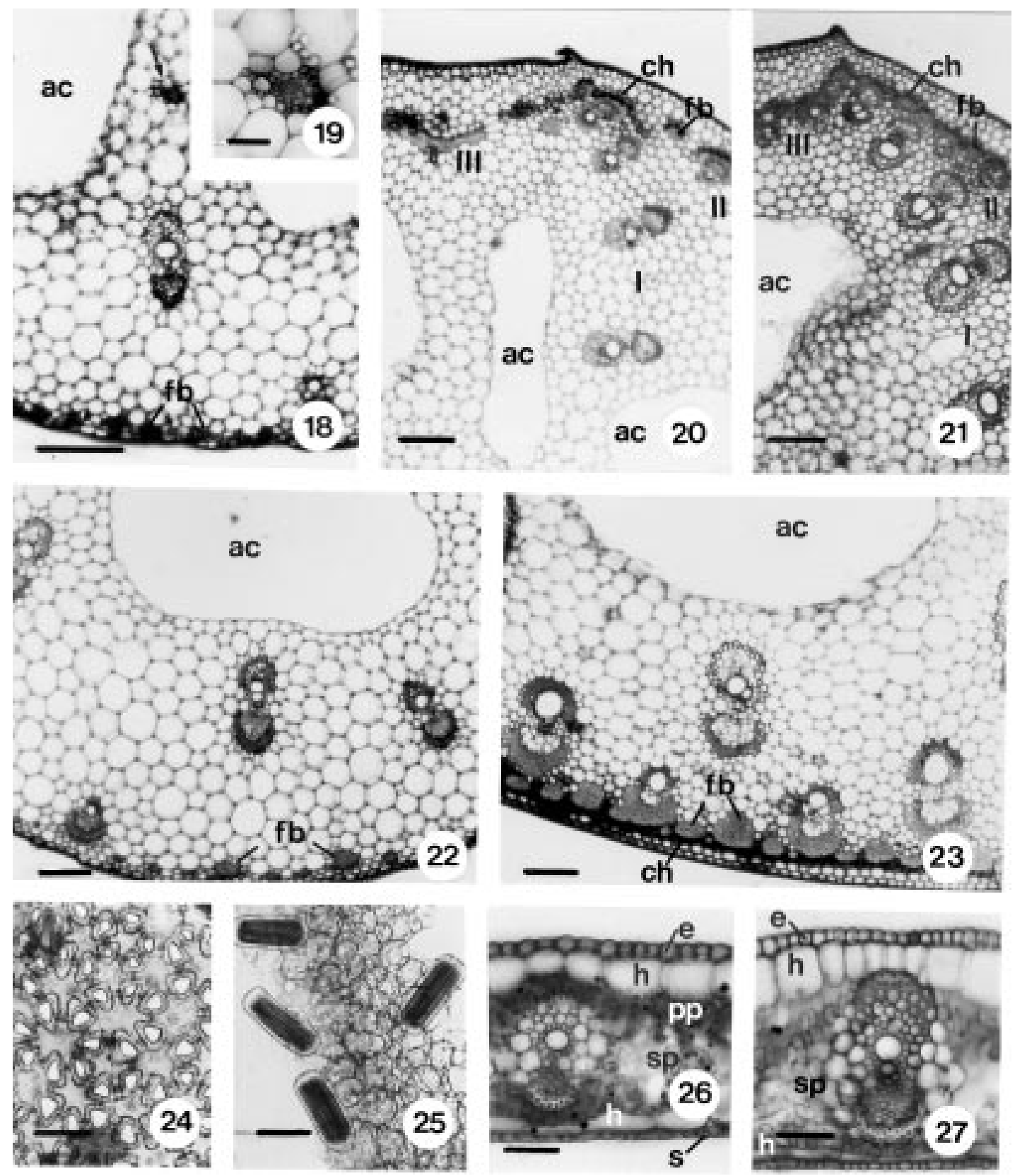

Figures 18-27. Foliar cross sections of Heliconia spp. 18-19. H. angusta. 18. Vascular bundles of the abaxial arc and air-canals (ac) from the leaf-sheath, arrow shows one inclined vascular bundle. Fiber bundle (fb). Bar $=255 \mu \mathrm{m}$. 19. The same inclined vascular bundle of the previous figure. Bar $=50 \mu \mathrm{m}$. 20-21. Adaxial surface from petiole with part of the three vascular systems (I, II, III). 20. H. angusta, fiber bundles (fb) and chlorenchyma (ch) are discontinuous. Main vascular system (I); abaxial vascular system (II); adaxial vascular system (III). Bar $=170 \mu \mathrm{m} .21$. H. velloziana, fiber bundles (fb) and chlorenchyma (ch) are continuous. Main vascular system (I); abaxial vascular system (II); adaxial vascular system (III). Bar $=170 \mu \mathrm{m} .22$ 23. Abaxial surface from petiole with vascular bundles. 22. H. angusta. Air-canal (ac); fiber bundles (fb). Bar $=170 \mu \mathrm{m} .23$. H. velloziana. Air-canal (ac); chlorenchyma (ch); fiber bundles (fb). Bar $=170 \mu \mathrm{m}$. 24. Stellate cells of the diaphragms in the foliar air-canals of $H$. velloziana. Bar $=50 \mu \mathrm{m}$. 25. Raphide-sacs present in the diaphragms of the foliar air-canals in $H$. angusta. Bar $=50 \mu \mathrm{m}$. 26-27. Middle part of the lamina between secondary veins. 26. H. angusta. Epidermis (e); hypodermis (h); palisade parenchyma (pp); stoma (s); spongy parenchyma (sp). Bar $=100 \mu \mathrm{m}$. 27. H. velloziana. Epidermis (e); hypodermis (h); spongy parenchyma (sp). Bar $=50 \mu \mathrm{m}$. 
being discontinuous in $H$. angusta (figure 20) and continuous in $H$. velloziana (figures 21,23 ).

The adaxial epidermis of the lamina in the secondary veins region is characterized by cuboidalrectangular cells in $H$. angusta (figure 26) and cuboidal cells in $H$. velloziana (figure 27). The uniseriate abaxial hypodermis shows cells smaller than the adaxial one (figures 26,27 ). The chlorenchyma presents 1-2 layers of palisade parenchyma on the adaxial surface (figure 26), and 2-5 layers of spongy parenchyma on the abaxial surface (figures 26, 27).

Scapes - The epidermis is uniseriate, with small rectangular thin-walled cells in the proximal part (figures 28, 29) and thick-walled ones in the distal part (figures 31,33). Subepidermal cells from the distal part have thickened walls (figures 32, 33).

The distal part of the scape in $H$. velloziana presents 2-3 layers of chlorenchyma below the subepidermal layer (figure 33). Fiber bundles of the distal part in $H$. velloziana form a continuous cylinder below the chlorenchyma (figures 32,33), while in $H$. angusta they are discontinuous (figures 30,31 ).

Collateral vascular bundles are enclosed by a double-sheath such as the ones found in leaves: the external one of endodermal origin with thin-walled cells and the internal one of pericyclic origin, with thick-walled cells (figures 29, 31). In both species, starch grains were observed in parenchymatous cells of the proximal area, as can be observed in $H$. angusta (figures 28, 29).

\section{Discussion}

H. velloziana forms larger shoots with up to $3.50 \mathrm{~m}$ in height in open areas. H. angusta is found mainly in shaded places, forming smaller shoots, about $0.70 \mathrm{~m}$ in height inside the forest, while those found at the border of the forest reach about $1.75 \mathrm{~m}$.

According to Kress (1990a) Heliconia species found in open areas achieve a larger size than those species restricted to shaded areas. This fact probably is due to the differences in the light intensity and to the degree of vegetative competition that occurs among the different species in these habitats (Stiles 1975), therefore explaining the difference in the size of the shoots observed in $H$. angusta and $H$. velloziana.

The basic anatomical features of roots, rhizomes, leaves and scapes of the studied species are similar to those described by Tomlinson $(1959,1969)$ for other species of Heliconia.

Remains of epidermal cells present in mature roots can be interpreted as a substitution of the epidermis by the exodermis, as a covering tissue, as the root gets older. According to Von Guttemberg (1968) the exodermis of some species can work as a protecting layer in roots which do not form polydermis, as observed in the studied roots of $H$. angusta and $H$. velloziana.

The exodermis with slightly thick-walled cells, as found in $H$. angusta and $H$. velloziana, is also observed by Tomlinson $(1959,1969)$ in roots of other Heliconia species. Calathea commoriana Kennedy and $C$. lindbergii Peters (Marantaceae) present a multilayered exodermis of thick-walled cells, while another species of this family, Maranta bicolor Ker Gawl., shows exodermal cells little differentiated (Uliana 1999), similar to those cells found in H. angusta and H. velloziana. Both the Heliconia species and those of Marantaceae studied by Uliana (1999) are growing in the same environment, in an understorey in the Atlantic forest. Further studies of other Zingiberales are necessary to understand the possible significance of this character in these species.

The development of air-canals in $H$. angusta and $H$. velloziana roots is perhaps an answer to the growth of these roots in soil with a high availability of water. The decrease of oxygen concentration in the soil, created by temporary flooding, increases ethylene concentration in roots of plants, which in turn increases the cellulase activity, resulting in the aerenchyma development (Smith \& Russell 1969, Kawase 1979, Kawase \& Whitmoyer 1980).

These species grow in the herbaceous stratum, close to the flow of water, where the soil presents high availability of water in different months of the year, suggesting that the development of aerenchyma in their roots is an adaptation to that moist condition.

The cortical structure of roots in H. angusta and $H$. velloziana is a characteristic of other members of Zingiberales, as Musa acuminata cv. Gros Michel Musaceae (Riopel \& Steeves 1964), and Maranta, and Calathea - Marantaceae (Uliana 1999). According to Williams (1947) and Heimsch (1951), the organization of inner cortical cells in radial rows is a result of periclinal divisions of the innermost cortical layer, named proendodermis, that in the mature root, later on is differentiated into endodermis (Van Fleet 1961). 

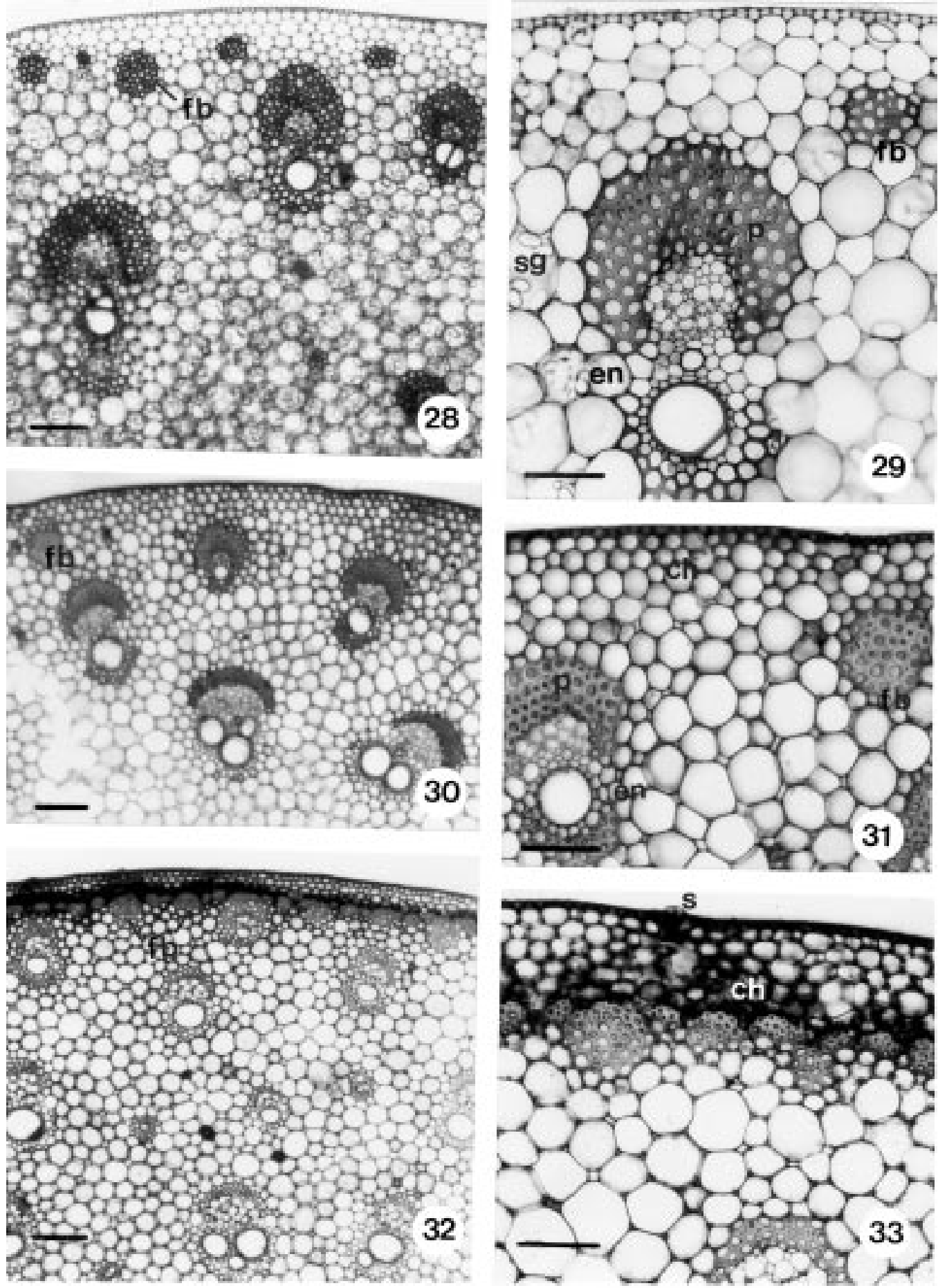

Figures. 28-33. Cross sections of the scape of Heliconia spp. 28-29. Proximal part of the H. angusta scape showing fiber (fb) and vascular bundles and numerous starch grains. 28. Bar $=170 \mu \mathrm{m}$. 29. Endodermis (en); fiber bundle (fb); pericycle (p); starch grains (sg). Bar $=100 \mu \mathrm{m}$. 30-31. Distal part of $H$. angusta. Fiber bundle (fb). Bar $=170 \mu \mathrm{m}$. 31. Discontinuous chlorenchyma (ch) and fiber bundles (fb). Endodermis (en); pericycle (p). Bar $=100 \mu \mathrm{m}$. 32-33. Distal part of H. velloziana showing the continuous chlorenchyma (ch) and fiber bundles (fb). Bar $=170 \mu \mathrm{m}$. 33. Chlorenchyma (ch); stoma (s). Bar $=100 \mu \mathrm{m}$. 
In some species of Heliconia, Tomlinson (1959, 1969) reported phloem strands inside the vascular cylinder as phloem islands, and these are not found on the studied species. Tomlinson (1962) suggested that these strands in some species of Heliconia are vestiges of an anomalous stele, which still exists in species of Strelitziaceae and Musaceae, families related to the Heliconiaceae.

The anatomical features of rhizomes are similar in both studied species, except for the larger number of fiber bundles in the peripheral cortex of $H$. velloziana. This species has a larger size and consequently needs a larger amount of the supporting tissue.

The uniseriate hypodermis and narrow mesophyll of the blade is similar in both species, according to those presented by Tomlinson (1959, 1969) and Rundel et al. (1998) for other Heliconia species. These features were also observed by Triplett \& Kirchoff (1991), except for the fact of a biseriate hypodermis next to the longest vascular bundles, in some species, such as in $H$. platystachys Baker, $H$. pendula Wawra and $H$. latispatha Benth.

According to Skutch (1930) the hypodermis is responsible for the unrolling of young leaves; Rundel et al. (1998) suggest that the hypodermis could decrease the impact of the sunlight in the photosynthetic tissue; probably the hypodermis could be performing both functions in $H$. angusta and $H$. velloziana.

The main anatomical difference found in the leaves of $H$. angusta and $H$. velloziana is the distribution of the fiber bundles, confirming the possible diagnostic value of this characteristic for the Heliconia species observed by Tomlinson (1969). In H. velloziana leaves these fibers generally form an almost continuous layer, close to the abaxial surface.

The presence of inclined vascular bundles, i.e. inclined to other vascular bundles, in the midrib region and in the sheath region of leaves in H. angusta and $H$. velloziana, was also found in species of Marantaceae (Uliana 1999). However in Marantaceae the vascular bundles are reversed, which can be representing an important character in the phylogenetic studies of Zingiberales, since many authors, such as Tomlinson (1962) and Kress (1990b), consider the Marantaceae more derived than the Heliconiaceae.
Raphide sacs are found between the palisade and spongy parenchyma of the lamina; they are generally in parenchyma cells of the air-canals in the foliar leaf-sheath, petiole and midrib, and on the cortical area of rhizomes and roots as mentioned by Tomlinson (1959) for all species of Musaceae (s.l.). These crystal-bearing cells are also observed in $H$. angusta and $H$. velloziana in those different vegetative organs, probably protecting the plants against herbivorous, such as insects.

Scapes of Heliconia species are characterized by a larger quantity of fibers in the peripheral area, associated or not with the vascular bundles. The continuous distribution of fibers, also observed in leaves of $H$. velloziana, is probably related to its largest size, also having its taxonomical value according to Tomlinson (1962).

Anatomical characteristics such as: air-canals in the different organs, the wide foliar blade with narrow mesophyll, and slightly thick-walled epidermal cells, show that both species are adapted to the conditions of the understorey where they live, and where there is practically no shortage of water.

The distribution of fibers present in leaves and scapes, can be of taxonomic use, due to the differences found in these species. Anatomical studies with a greater number of Heliconia species, including species from other vegetation types, can enable an increase of the information and the confirmation of the taxonomic value of these characteristics to the family Heliconiaceae, besides other information about the anatomical adaptations in these species.

Acknowledgements - We thank the Conselho Nacional de Desenvolvimento Científico e Tecnológico $(\mathrm{CNPq})$ for supporting this study.

\section{References}

CESAR, O. \& MONTEIRO, R. 1995. Florística e fitossociologia de uma floresta de restinga em Picinguaba (Parque Estadual da Serra do Mar), município de UbatubaSP. Naturalia 20:89-105.

CRONQUIST, A. 1981. An integrated system of classification of flowering plants. Columbia University Press, New York, p. 1157-1172.

DAHLGREN, R.M.T., CLIFFORD, H.T. \& YEO, P.F. 1985. The families of the monocotyledons. Springer-Verlag, Berlin, p.350-358.

HEIMSCH, C. 1951. Development of vascular tissues in barley roots. American Journal of Botany 38:523-537. 
JOHANSEN, D. A. 1940. Plant microtechnique. McGrawHill Book Company, New York.

KAWASE, M. 1979. Role of cellulase in aerenchyma development in sunflower. American Journal of Botany 66:183-190.

KAWASE, M. \& WHITMOYER, R.E. 1980. Aerenchyma development in waterlogged plants. American Journal of Botany 67:18-22.

KRESS, W.J. 1985. Bat pollination of an Old World Heliconia. Biotropica 17:302-308.

KRESS, W.J. 1990a. The diversity and distribution of Heliconia (Heliconiaceae) in Brazil. Acta Botanica Brasilica 4:159-167.

KRESS, W.J. 1990b. The phylogeny and classification of the Zingiberales. Annals of the Missouri Botanical Garden 77:698-721.

NAKAI, T. 1941. Notulae ad Plantas Asiae Orientalis. Journal of Japanese Botany 17:1-15.

RIOPEL, J.L. \& STEEVES, T.A. 1964. Studies on the roots of Musa acuminata cv. Gros Michel - 1. The anatomy and development of main roots. Annals of Botany 28:473-490.

ROESER, K.R. 1962. Die Nadel der SchwarzkleferMassenprodukt und Kunstwert der Natur. Mikrokosmos 61:33-36.

RUNDEL, P.W., SHARIFI, M.R., GIBSON, A.C. \& ESLER, K.J. 1998. Structural and physiological adaptation to light environments in neotropical Heliconia (Heliconiaceae). Journal of Tropical Ecology 14:789-801.

SANTOS, E. 1978. Revisão das espécies do gênero Heliconia L. (Musaceae s.l.) espontâneas na região fluminense. Rodriguésia 30:99-201.

SKUTCH, A.F. 1930. Unrolling of leaves of Musa sapientum and some related plants and their reactions to environmental aridity. Botanical Gazette 90:337-365.
SMITH, K. \& RUSSELL, R.S. 1969. Occurrence of ethylene, and its significance, in anaerobic soil. Nature 222:769771 .

STILES, F.G. 1975. Ecology, flowering phenology, and hummingbird pollination of some Costa Rican Heliconia species. Ecology 56:285-301.

TOMLINSON, P.B. 1959. An anatomical approach to the classification of the Musaceae. Journal of the Linnean Society 55:779-809.

TOMLINSON, P.B. 1962. Phylogeny of the Scitamineae morphological and anatomical considerations. Evolution 16:192-213.

TOMLINSON, P.B. 1969. Commelinales-Zingiberales. In Anatomy of the monocotyledons. Vol. III. (C.R. Metcalfe, ed.). Oxford University Press, Oxford, p.295-324.

TRIPLETT, J.K. \& KIRCHOFF, B.F. 1991. Lamina architecture and anatomy in the Heliconiaceae and Musaceae (Zingiberales). Canadian Journal of Botany 69:887-900.

ULIANA, V.L.C.R.. 1999. Morfo-anatomia de espécies de Marantaceae do Núcleo Picinguaba, Ubatuba, SP Dissertação de mestrado, Universidade Estadual Paulista, Rio Claro, SP.

VAN FLEET, D.S. 1961. Histochemistry and function of the endodermis. Botanical Review 27:165-220.

VON GUTTEMBERG, H. 1968. Der primäre Bau der Angiospermenwurzel. In Encyclopedia of plant anatomy. v.8, Gebrüder Borntraeger, Berlin.

WILLIAMS, B.C. 1947. The structure of the meristematic tip and origin of the primary tissues in the roots of vascular plants. American Journal of Botany 34:455-462. 